\title{
Ethics in Ancient India: In the Specific Context of Sanskrit Texts and Human Values
}

\author{
Kaushalya
}

\begin{abstract}
Deontology works as a fundamental element in all fields of human life. It is explained elementarily through one of the branches of elementary knowledge. At the end, the direction and vision of deontology is the positive development of human society, which is also termed as ethics, but it needs to be understood that whether the development of consciousness of society is inclusive or related to a particular section of society is decided by the fundamental values of 'Nitišāstra' or Deontology. It means that they would not be helpful in developing an inclusive society if the basic values of deontology or Nitîsāstra, are driven from the base of a feudal system, then it may not be able to develop our society. Our values will only work for inclusive growth if the roots of the system have human values. Ethical values actually differ according to not only diverse cultural and traditional practices world over, but also at national and regional levels. It is also possible that there is diversity in these values because of the class and feudal cultures could have influenced them. My study aims to keep this in mind and present this subject.
\end{abstract}

Index Terms-Hindu social order, Varan-vyavsthā, Nitīśāstra.

\section{INTRODUCTION}

Deontology works as a fundamental element in all fields of human life. It is explained elementarily through one of the branches of elementary knowledge. At the end, the direction and vision of deontology is the positive development of human society, which is also termed as ethics, but it needs to be understood that whether the development of consciousness of society is inclusive or related to a particular section of society is decided by the fundamental values of 'Nitisśāstra' or deontology. It means that they would not be helpful in developing an inclusive society if the basic values of deontology or Nitisśāstra, are driven from the base of a feudal system, then it may not be able to develop our society. Our values will only work for inclusive growth if the roots of the system have human values. Ethical values actually differ according to not only diverse cultural and traditional practices world over, but also at national and regional levels. It is also possible that there is diversity in these values because of the class and feudal cultures could have influenced them. My study aims to keep this in mind and present this subject.

\section{STUDY}

Manuscript received May 11, 2016; revised December 23, 2016

Kaushalya is with Motilal Nehru College, University of Delhi, India (email: panwar.kaushal@gmail.com).
Though there have been diverse opinions on Ethics and conduct in every age but this can be said very clearly that deontology is the study and analysis of the general principles of the human activities and objectives. Most writers and philosophers have expressed consensus that deontology is focused more on values and standards and it is obviously not a study of any conditions but it is more about analysis of individuals and also that of society at the macro level.

Various branches of deontology have evolved over the years and some of them have focused more on the "moral decision" and raised issues on the foundational basis of the root cause of human conduct on the basis of right or wrong. There are two aspects of deontology: one is centered on thoughts and the other on directions both of which are integrated and indivisible.

Deontology is the branch of knowledge in which we study the laws related to ethics. It is termed as Nitisisastra in Sanskrit which is made of words Nit̄̄ and shāstrā. Shāstrā means laws or traditions while Nitī means direction or behavior. Niti is generally used in judicial systems or for prevailing laws. It is basically the activities which take you from the wrong to the right path. Generally, Nitī is used for judicial system and prevailing law. Nitī is basically a way to take one to right path from the wrong one. The word Nitī was coined in the Sanskrit-Hindi dictionary by Shivrām Bāman Āpte for direction, ethics, conduct, behavior, work pattern, daily behavior and traditions. It is literally termed in Sanskrit as Nayanāt Nitīruchyate. In his Arthshāstra, Ācharya Brihaspat elaborates that achievements of Trivarga is the outcome of Nitī. Basically, your behavioral system, knowledge of governance, knowledge of ethics, conduct, fraternity, helping others, the pattern of work which makes others happy too can be defined as Nitī. It implies that the meaning of Nitiśāstra is basically the law of following certain 'traditions and customs.' Hence, Nitisisāstra or ethics developed into embracing 'morality'. It can also be defined as a philosophy of morality. The term 'Naitik' in English is generally translated as 'moral', which is born out of the word 'Mores' in Latin which actually means traditions and cultural practices. Therefore, Nitisisāstra is also called as the science of traditions or customary practices. This evaluates the cultural practices, voluntary duties and conducts of the individuals and analyses their 'right' and 'wrong' duties and its various kinds are defined by morality and remained in the philosophical realm while Nitī is considered to be a guiding force. Hence Nit̄̄ in Nitīśāstra and Achār in $\bar{A}$ chāraśāstra seem to be synonymous to each other. 
Upanishads view Brahma as the epitome of high moral values, where you get emancipated from the hypocrisies of Sukha-Dukha, Rāga-Virāga etc. This actually provides seeds for Nișkām karma. The Varnaśram dharma has been accepted as a mean, while in the famous Gāyatri Mantra prayers are meant for positive intellect. There are prayers such as 'asto ma sadgamayah, tamso ma jyotirgamaya' which actually are very positive in approach where you ask for the almighty to take you from darkness to enlightenment. In the Upanishads Tapa actually means Puruṣārtha, which has a positive connotation and does not really mean 'machoism.' Hence Vrata i.e. fasting is considered to be the foundation of knowledge and credibility. The basis of Nitiśāstra is to understand oneself. Hence, an ignorant person gets 'death' whilst the enlightened one gets mukti or 'liberation' beyond death. The Nitisisāstra was formed to guide the society and make it better and hence it preached society to respect Dharma, speak the truth, Tapa, concentration, tolerance, prayer for peace, daily ritual of 'havan', welcoming the guests, believing in humanity and believing in creationism. This was meant to make a better society.

Beginning from the ancient days, this Nitissāstra is still active, directing the characteristic behavior of human beings. These are the values of our society. Every society changes according to morality, and basic characteristics and behaviors, but they are never accepted in their form of origins. In Vedas, Nitīisāstra comes as Ritu which is sovereign and uniform and used to mean 'noble conduct' or Sadāchāra. In Yajurveda, Yajñas are explained to make human lives ideal In the Atharvaveda, there are certain laws of ethics which say that offerings make your next life 'pure' along with this. The prayers have been organized at many places to save one from sins. For a married family, it is said that if the family gets prosperity, the couple will remain united all through life. While for married women, it is prayed that she conduct herself according to her husband's needs so that the mind remains positive, and there is no animosity among brothers and sisters, and all follow one path to 'welfare' or Kalyāna [1].

In the post-Vedic society, we get a lot of knowledge related to moral values and religious ideals through Brahmin literature, which seems to be able to push us towards happiness and progress. According to these brahmanical texts, human life symbolizes Yajña [1]. Narrating the importance of Tapa along with truth and knowledge; they explain that all the basic human elements, everything meant for Grihsthāśram and other things are born due to deep Tapa like Sādhanā of Vedas.

One should never ignore the servants and guests at home and only left-over food should be taken at the end after the guests as well as servants have finished their food. We should try to fulfill the financial needs of our guests and should maintain relations with a wife only. Those who follow this never suffer from the lack of Agnihotra and get fruits of Dașapurnamāsa Anuṣthāna. In the brahmanical texts, Niti is considered to be an essential requisite to run the country orderly. Wishing for a better life is equivalent to wishing for a life with ethics. In Brahmin literature, truthful speech, truthful conduct and truthful action were the main Dharma of Brahmin Yuga. Deceitful behavior and speeches were considered sin. Theft, looting and abusing were considered sins. The man was always preached to be laborious because a laborious man actually gets both madhu i.e. honey and fruits. Sun is always worshipped globally for being in motion all time. The behavior according to Dharma is the duty of human beings and Yajña is also considered right Dharma. For women, allegiance and loyalty to their husband is considered ominous. The ethical values do not just save us from degradation but also inspire us to follow the way to progress.

In Raghuvamșam, Kalidasa said that Smritis follow Vedas like shadows [2]. In the Smritis, Dharma itself is referred as Āchāra Saṃhitā or ethics. Dharma is explained with 10 signs as Dhriti, Kșama, Dama, Asteyam, Shauch, Indriya Nigraha, Ghi, Satya (truth) and Akrodh (never getting angry).

According to Manu, the place of human being in society and his duties are based on the Varna Dharma [3]. Manu considered Varna division as useful and absolute for society. Many times, man faces such conditions that a generalized Varnāśram Dharma cannot work accordingly. Hence Manu described Apaddharma for such special situations. Manu has provided four foundational sources for Āchāra and they are Dhriti, Smriti, Sadāchāra and Antahkaraña. Rāmāyaṇa and Mahābhārata have been placed together as Mahākāvya i.e. epic. Rāmāyaṇa is the ancient epic which was born out of idolization of an invented ideal man in which Lord Rama's character is depicted as Maryādā Purusottama and Mangalakārī, which means one who benefits other. Mahabharata too establishes Yudhishthira as the avatar of Dharma and Satya, while Bhishmapitamah depicted as a devotee and religious human being [4]. In that Bhishma has given instructions on deontology to Yudhistra as to how to go about administering agriculture commerce punishment to enemies, army, spies, the appointment of military commander, the annihilation of enemies and the defense of the fort and its treasury etc. There were many other aspects including all the ways to suppress the enemies, the honor and respect to intellectuals, worshipping of Sadhus, society and festivals, assembly and conduct.

Gita is that part of Mahabharata the subject of which is the quest for morals. Bhagwad Gita 'answers' doubts which arise at various phases of life and also explains various facets of our regular life. In place of material knowledge, Bhagwadgita is more suited to the study of deontology. It has propagated a way of selfless way of amalgamating the Brahmvidyā and Yogaśāastra. Lord Krishna has explained Dharma and Kartavya i.e duties in Gita and says that, 'I have formed four Varnas on the basis of Guna and Karma of human beings'[5]. But in reality the divisions of Chaturvarna seem more like watertight compartments wherein a meritorious shudra or woman has no right to higher attainments in life. Geeta and Mahabharat have several instances of violation of natural justice and rejection of the democratic principles of equal treatment and equal opportunity. The rejection of Eklavya and dehumanisation of Karna are the examples of denial of equal opportunity 
and denial of human dignity. All these wrongs are done only to maintain the supremacy of a few over the large majority of masses who are recognized today as low castes or Bahujans. Several ethics in war and in normal social life are violated in the Brahinical literature to gain social, political and cultural hegemony over the Shudras and women. Unfortunately, this kind of literature has been considered as the 'ideal'(model) for Indian society for centuries.

The idea of Charvak is purely materialistic. The kingdom of man is his body. An active body is a distinct quality. The objective of human life is to create more and more joy. Since Death kills each and every dimension of Human personality, therefore, it is completely waste to care for anything after death such as heavens. Pain is generally mixed with joy but one would be foolish to discard joys because of pains. Each person has to care for one's own joys. The followers of the Charvak philosophy never believed in the power of 'God' and the origin of Vedas as well as other supernatural acts, but they had definite faith in the concept of an ultimate 'truth', earning livelihood through 'proper' ways, mutual understanding, honest behavior in agriculture and business. Animal husbandry, agricultural business and politics will only succeed if they are carried out with honesty and commitment. It clearly shows that Charvak actually believed more in morality or good conduct in some form or other.

In the Nitisíastra, the path suggested by Mahatma Buddha was a middle path or Madhyam mārga or Madhyam Pratipadā. When the society was infested with multiples social evils, Buddha undertook the mission of rebuilding the society on the pillars of compassion, Karuna, Maitri, equality, brotherhood etc. Bahujan hitay and bahujan sukhay (the maximum good of the maximum people) was the motto. To reform the unjust social order, he preached in Pali - the language of the masses. He denied the authority of Vedas and Shatras which were the bedrock of Brahminical ideology. Thus Buddha encouraged rational thinking and scientific approach to life. The main 'characteristic' of Buddhism was its philosophy. Accordingly to Buddhism, there are four noble truths which are part of the Dhammachakkapabattan Sutta:

1) This world is full of suffering i.e. Dukha.

2) There is a cause of suffering. i.e. Samudaya(The rising of Dukkha)

3) Suffering can be eliminated. i.e. Niroda (The Cessation of Dukkha)

4) Elimination of suffering is possible by practising the Eightfold Path. i.e. Magga (The Eightfold Path). It is also known as the "Middle Path (Majjhima Patipada) [6].

He said that only the Karma which is good (kusal) gives good results which makes everyone happy. If Karma is incorrect (akusal), it gives pain to you and others. In all the four 'Arya-truths', the fourth one which is known as 'Dukhnorodhi mārga' is the foundation of deontology. Its practical form lies in 'madhyam pratipada' $\bar{a}^{\prime}$ or the middle path. Usually people in society practice two extreme forms of desires. On the one side, there is self deprivation and on the other there is a chase for transient pleasures but Buddha does not approve of the extremes. Right conduct is fundamentally a movement away from these two extreme courses of life. The ardent following of the middle path is the surest way to overcome the pangs of cause and effect sequence. Practice of the Eightfold path leads to Nirvana when people practice good karmas like Daan, Sheel, Samadhi and Pañ̃na. This may also help to overcome the repetitive circle of life and death - the Nirvana which is the release from the cycle of life and birth. The Buddha never imposed his ideas on others. He told his followers not to accept anything preached by him just because He said it. The followers should verify his teachings on the basis on rationality and logic; and accept it only if they are convinced about it. The Buddha declared that He is not the "Mokshadata" (one who offers salvation) but a "Margadata"(one who shows the path). He advised his followers, "Be Your Own Light" ! In Buddhist texts, there is a very positive description of the notion of Nirvāna and it is being said that no man should be content with the achievement of individual salvation rather he/she has to be in constant pursuit of the welfare of others towards the same fulfillment. Love, empathy, grace and seeking oneness with the whole humanity are the core qualities of Buddhist Deontology.

Jain religious philosophy is centered on achieving the original purity of soul and that is termed as the highest objective. The biggest obstacle in that is the "karmas" which have polluted the soul just like clouds cover the clear appearance of the sun.

The main specialty of Jain ethics is non-violence. To follow the path of non-violence vigorously, many Jains still walk carefully and also despise many things which they feel have 'life', including honey. We can't see many lives, but we can assume about them rationally. Only enlightenment can overcome the darkness of life, and hence great emphasis is laid on Samyak Jñan, Samyak Darśanānd, Samyak Charitra.

Both individual and society have been included in our ethical debates since Vedic period and they go on till today. The overall development of human being is only possible through Purușārtha. It is the basis, by following which, he lives and commits his various duties. In Indian ethics whichever are considered the fundamental and accepted values, Purușārtha is something which seems to be forming the basis of ethics. It suggests that overcoming Trividh Dukha alone is Purușārtha. The question is whether men in different societies are following these ethical values according to these defined texts. Can we say that these things were followed in each society in one particular way?

India is a caste-based society where caste discrimination is prevalent since ancient times in the brutal forms; hence some questions can be raised on the morality of 'ancient' Indian culture. There are numerous TV serials on epics and other holy scriptures which we do like very much. The question is why a woman has to face discrimination on the moral questions in our ancient Indian ethical values? Why is she confined inside the four walls of the house to depict an 
'ideal' woman? If the King was the representative of God then what was the role of the Queen? How many women wrote epics, Smritis, Vedas and Puranas? We get only a few women as examples. Isn't it true that our society had separate moral values for women? For example Manu's law asks that women should never ever try to be separate from their husbands, fathers or sons. If any woman even comes across such a thought, she is believed to have condemned both her parents' as well as husband's families. A person who is obsessed with Karma, whether an 'intellectual' or an ordinary man, women are able to take on the 'wrong' side. A woman whose husband has gone out should not play with others, nor should she wear good ornaments, should avoid going out in public programmes or festivities, or even avoid going to other people's house. She should not even smile. The condition of the Shudra women was worse as they were termed as 'engaged in prostitution'. The wives of Shudra men could only hail from Shudra varna while Vaishyas could have wives from the same Varna or from Shudra varna too. The Kshatriyas were allowed to have wives from Vaishya and Shudra Varna as well as his own Varna while the Brahmins could have wives from all the three or their own Varna [7]. Clearly, Brahmin men were allowed to marry from any of the four Varnas. It is unambiguous here that 'ethics' for women have been defined according to the suitability of Brahmin men only.

Since ancient times there are two kinds of ethics floating in our society. There are four Varnas. These are Brahmin, Kshatriya, Vaishya and Shudra. There is one more which is outside these four Varnas. These are termed as 'untouchable'. In today's language they are commonly addressed as the Dalits though the term "Dalit" includes Shudras untouchables, all women and some exterior exploited castes. Do our ancient texts have common ethics for all? Were there similar duties for all? Each community had separate ethics and it differed for all. For e.g. Brahmins, Kshatriyas, Vaishyas and Shudras, all have different ethical values. There were different ethical values decided for the Shudras and untouchables. Don't we know what they were? What were their value systems? What was ĀchāraVyavhāra? These value system, ethics, morality etc., actually decide our mentality, action plan and activities as well as our behaviour pattern. If Manu said that knowledge is not meant for the Shudras and if the shudra gets to hear something even by mistake then molten 'lead'(metal) must poured into his ear. It exemplifies that Shudras and 'untouchables' did not have right to knowledge and education.

This ethic or thought has developed the mindset in our society which feels that knowledge, education, ability, capacity aare not meant for 'everyone' and is definitely not the domain of the Dalits and the backward communities. It is the same mindset which says that the mind of a woman is in her 'knees'. How was this mindset 'built'? We must remember that when Buddha had challenged the established norms and traditions of Brahminical ethics and opened the doors of education for women and Shudras, then Chanakya had said that 'prostitutes' and Shudras needed Viharas which Gautama Buddha has provided for them.
The question before us is that what kind of 'morality' was working here? It seems that our ancient Indian ethics were basically working for feudal and casteist values. If there were human values working during this period Nitisisāstra would have really played an important role for the uplift of our society.

\section{CONCLUSION}

In this research paper, mainly two ethical streams of Vedic and Buddhist values have been studied and analyzed. There is also an attempted to see here as to which one is the original system. The information that we got through research papers and reference materials have been included in the paper and attempt was made to discuss them here.

From Whatever references and study material that were available, it seems that the foundation values of Vedic ethics were class and Varna values of exclusivism and hence could not guarantee human values and constructive development of all. It is because of such an 'exclusive' ethical value system that a large part of the society lives in absolutely wretched and unjust conditions. Also, the social, economic and political system based on such ethical values always turns unilateral. Parallel to this, we have also analyzed and explained the progressive attitude towards inclusiveness in other ethical value systems of India such as found in Buddhists and other literature. Every man or woman from any walk of life irrespective of his/her social location was welcome in the fold Gautam Buddha. Therefore we find kings, queens, businessmen, courtesans, untouchables and even criminals like Angulimal or a great dancer Amrapali came to the Buddha and became arahats (enlightened). A human value based Nitisisástra or ethics, by giving equal status to all human beings, can contribute towards the healthy development and positive interaction among different sections of society.

\section{REFERENCES}

[1] D. Rāth and W. D. B. Barlin, Atharved, Bombay: Sāayaṇa Bhashya sahit, 1865.

[2] Kalidasa, Raghuvansham, Varanasi: Chaukhamba Publishers, 2002.

[3] D. S. Kumar, ManuSmriti, Delhi: Arsh Sahitya Prachar Trust, Fifith Edition 2000.

[4] P. C.Rao, Māhābhārat, 1889-1892.

[5] Bhāgwad Gìtā, Gītā Press, Gaurkhpur, Samvant 2026.

[6] W. Rahula, What the Buddha Taught, New York: Grove Press, 1969, P-32.

[7] S. Gani, Vedakālīn Samāj, Chaukhmba Vidya Bhavan, Varanasi, 1887.

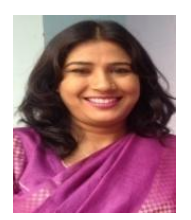

Kaushalya is presently assistant professor of Sanskrit in Motilal Nehru College, University of Delhi, Benito Juarez Marg, New Delhi, India. She has done her doctoral research on Dharmaśāstra Men Śüdra : Pramukha pāịdulipiyon் ke viśeșa sañdarbha men், from Jawaharlal Nehru University, New Delhi 2009, M.Phil in Sanskrit (2002-2003). Her major literary interests include Study of Dharmaśāstra and position of Śhūdras (Śhūdrās woman) in Ancient History, Varna-System, Casteism, Language of Shudra and woman, Social movements in India. She has six major book publications to her credit. She has presented $11^{\text {th }}$ national level papers and $7^{\text {th }}$ International papers in abroad like Harvard University, Imperial College London, Switzerland, University of Massachusetts, Boston U.S.A. The National Commission of women Govt. of India presented an award as an "Outstanding Women" on the occasion of 
International Women Day. She has been awarded the "Ambedkar in India Samman 2012" for her contribution of writing, journalism, inhalation of untouchables given by Ambedkar in India Magazine published from Kushinagar UP. Star Plus TV Interview: Satyamev Jayate Dated $10^{\text {th }}$ Jun 2012, Loksabha TV, Special Report on Caste Issues, 2012, DD News TV,
"On the occasion of "International Woman Day" dated $8^{\text {th }}$ March 2013 , Rajyasabha TV, Special Report on Manual Scavenging Dated $25^{\text {th }}$ April 2013, DD News Urdu TV, $125^{\text {th }}$ Birth Anniversary of Baba Saheb Bhim Rao Ambedkar, $3^{\text {rd }}$ November 2015, Rajyasabha TV on International Woman Day on $8^{\text {th }}$ March, 2016. 